\title{
Urgences
}

\section{À ce moment-là...}

\section{Jean Cossette}

Numéro 15, octobre 1986

Épigraphiques

URI : https://id.erudit.org/iderudit/025312ar

DOI : https://doi.org/10.7202/025312ar

Aller au sommaire du numéro

Éditeur(s)

Urgences

ISSN

0226-9554 (imprimé)

1927-3924 (numérique)

Découvrir la revue

Citer ce document

Cossette, J. (1986). À ce moment-là... Urgences, (15), 46-46.

https://doi.org/10.7202/025312ar

Ce document est protégé par la loi sur le droit d'auteur. L'utilisation des services d'Érudit (y compris la reproduction) est assujettie à sa politique d'utilisation que vous pouvez consulter en ligne.

https://apropos.erudit.org/fr/usagers/politique-dutilisation/
Cet article est diffusé et préservé par Érudit.

Érudit est un consortium interuniversitaire sans but lucratif composé de l’Université de Montréal, l'Université Laval et l'Université du Québec à Montréal. Il a pour mission la promotion et la valorisation de la recherche. https://www.erudit.org/fr/ 


\section{Jean Cossette}

Il ne suffit pas, pour écrire, d'attirer l'attention et de la retenir. Il faut encore la satisfaire.

Joseph Joubert: Carnets

À ce moment-là, en plein soleil de midi, alors que tout espoir semblait éteint, la plume se mit à suer lentement de fines gouttelettes cramoisies... Il y eut tout d'abord un long frisson qui parcourut en entier le premier cercle des curieux, puis, presque simultanément, on entendit des "Hooo!" et des "Haaa!", vite aspirés comme si on ne voulait rien perdre du phénomène. C'était donc vrai! Cette plume-là suintait...

L'annonce du miracle se propagea telle un best-seller depuis la première rangée de la foule jusqu'à la dernière, située un demikilomètre plus loin et, à mesure que la vérité progressait au travers du peuple de moins en moins sceptique, une clameur s'élevait dans la campagne tantôt silencieuse.

L'heureux propriétaire de la plume miraculée pleurait pourtant à chaudes larmes, enfin récompensé par cette preuve tangible qui ferait taire, une fois pour toutes, les incrédules, les pyrrhoniens, les "barbares" comme il disait. Mais voilà que ses larmes, plutôt que d'émouvoir la galerie, provoquèrent une curieuse réaction dans les rangs.

- Regardez! Regardez! Il suinte lui aussi! s'écria une bigote en le montrant du doigt.

- C'est pourtant vrai! Regardez! Il suinte comme sa plume! renchérit agressivement sa voisine.

En quelques minutes, tout fut consommé... L'homme, sauvagement attaqué, dut satisfaire de sa personne la soif de reliques de ces insatiables fanatiques. Il ne resta bientôt plus de lui que quelques lambeaux de chair éparpillés sur l'herbe piétinée.

Dans la cohue et la bousculade sauvage, curieusement la plume avait été oubliée... Maintenant que les hystériques avaient refoulé leurs ardeurs vers les portes de la cité et que l'astre blêmissait sur la ligne d'horizon, la plume se remit doucement à suinter quelques gouttes de sang. Quelques gouttes de sang sur la terre des hommes... 